\title{
Central Post-Stroke Pain in Stroke Patients: Incidence and the Effect on Quality of Life
}

\author{
Zeynep KILIÇ1, Belgin ERHAN², Berrin GÜNDÜZ², Gülsün ISKA ELVAN³ \\ ${ }^{1}$ Clinic of Physical Medicine and Rehabilitation, Atatürk State Hospital, Antalya, Turkey \\ ${ }^{2}$ Clinic of Physical Medicine and Rehabilitation, Istanbul Physical Medicine and Rehabilitation Training Hospital, Istanbul, Turkey \\ ${ }^{3}$ Clinic of Physical Medicine and Rehabilitation, Ereğli State Hospital, Konya, Turkey
}

\begin{abstract}
Objective: The aim of this study was to investigate the incidence of central post-stroke pain in stroke patients and the effect of central post-stroke pain on quality of life.

Material and Methods: One hundred stroke patients (47 women, 53 men), admiting to the inpatient rehabilitation clinic or stroke outpatient followup clinic were included in this cross-sectional study. Patients with aphasia, intermediate and advanced levels of cognitive disorder, subarachnoid hemorrhage, arteriovenous malformation, tumor, traumatic brain injury and multiple sclerosis causing hemiplegia, having neuropathic pain and complex regional pain syndrome in the history were excluded. central pain was evaluated with Leeds assessent of neuropathic symptoms and signs pain scale (LANSS), quality of life was assessed with the Nottingham Health Profile.

Results: The mean age of the patients were $60.27 \pm 11.59$ years, stroke duration was 14.65 months (range 2-124). Hemiplegia was on the right side in 35 cases, left side in 65 cases. 77 patients had ischemic, 23 patients had hemorrhagic etiology. Twelve patients had central post-stroke thalamic pain. Central pain was related with a significant difference in the pain parameter of Nottingham Health Profile $(\mathrm{NHP})(\mathrm{p}=0.001)$.

Conclusion: The central post-stroke pain is a complication that should not be ignored because it is not rare and has negative impact on the quality of life of patients with stroke.

Keywords: Stroke, central post-stroke pain, quality of life
\end{abstract}

\section{Introduction}

Stroke is one of the most significant neurological diseases and has one of the highest incidences. It is an important health problem leading to disability. Post-stroke pain may be peripheral or central in origin and is due to damage to the nervous system secondary to stroke (1). Central pain is observed less frequently compared with peripheral-originating nociceptive pain.

Central pain due to a cerebral lesion was previously defined as thalamic pain; however, because cerebral lesions do not al- ways involve the thalamus and because patients with thalamic lesions do not always experience pain, central pain is now defined as central post-stroke pain (2).

Central pain is one of the most difficult types of pain to treat and rehabilitation is difficult. Ninety percent of cerebraloriginating central pain has a vascular origin (3). In $40 \%-80 \%$ of patients, central pain may develop within 1-2 months after stroke. On a 1-year follow-up after stroke, the incidence of central pain varies between $2 \%$ and $35 \%$, and central post-stroke

Address for Correspondence: Zeynep Kılıç, MD, Atatürk Devlet Hastanesi, Fiziksel Tıp ve Rehabilitasyon Kliniği, Antalya, Türkiye.

Phone: +90242345 4550 E-mail: drzeynepk@yahoo.com

Received: January 2014 Accepted: June 2014

OCopyright 2015 by Turkish Society of Physical Medicine and Rehabilitation - Available online at www.ftrdergisi.com

Cite this article as: 
pain may develop in $18 \%$ of stroke patients who have a loss of temperature sensation (6-10).

Central post-stroke pain is generally sharp on the hemiplegic side, lasts for a long time, and is paroxysmal (11). Central pain can have different qualities and be of varying intensities, and it may be spontaneous or stimulated by various factors. It tends to get better with time $(5,12)$. The most important diagnostic indicator for central post-stroke pain is the presence of somatosensory disorders accompanying the chronic pain. There is often abnormal pain and heat sensation on the side of the stroke $(4,6,13)$. Patients generally define their pain as "burningboiling" or "burning-freezing" in nature (5). In most patients, in addition to pain, dysesthesia, hyperalgesia, and allodynia can arise spontaneously or with stimulation $(6,13)$. Hypoalgesia occurs in some patients, and there is deterioration in vibration, touch, proprioception, and two-point discrimination (13).

Factors affecting the diagnosis, evaluation, and treatment of patients with central post-stroke pain include the few available treatment alternatives and the time relationship between stroke and the onset of pain (4). Although pain develops in the first month after stroke in most patients, it may also develop 6 months after stroke (6). The time gap between stroke and the arousal of pain may render its diagnosis more difficult (4). In addition, cognitive problems and speech disorders, which arise after stroke, make it more difficult for patients to express themselves. The evaluation of the quality of life in stroke patients provides significant benefits for determining approaches to patient care, detecting priorities, and patient follow-up.

Cognitive impairment after stroke, advanced age, depression, functional impairment, disability, medical problems, and some social factors negatively affect the quality of life (14-19). Pain secondary to medical problems after stroke, which may develop for a number of reasons, may impair the quality of life. This is particularly true of central post-stroke pain because it is more resistant to treatment (20). Therefore, the variability of factors affecting the quality of life in stroke patients should be considered using a multidisciplinary approach, and the patients should be evaluated whit this respect. The aim of this study was to investigate the incidence of central pain as a complication in our stroke patients and its effects on the quality of life.

\section{Material and Methods}

Local ethical committee approvel was obtained. 255 stroke patients either inpatient or outpatient who were treated at Istanbul Physical Medicine and Rehabilitation Training Hospital between June 2008- February 2009 were enrolled in the study. Hemiplegia due to subarachnoid hemorrhagie, arteriovenous malformation, tumor, traumatic brain injury, and multiple sclerosis were excluded from the study. Besides patients having neuropathic pain or complex regional pain syndrome were also excluded. Patients with aphasia and intermediate or advanced levels of cognitive dysfunction were also excluded to administer neuropathic pain assessments and quality of life questionnaires more reliably. Written informed consent was obtained from all patients. Data analysis was conducted on 100 patients who matched the criteria.

Epicrisis reports confirmed that each stroke diagnosis was established through the review of clinical findings and computed tomography-magnetic resonance imaging (CT-MRI) in the neurology clinics. The demographic features of the patients (age, gender, occupation, and educational status), duration of stroke, number of strokes, side of the lesion, dominant side, stroke etiology, CT-MRI findings, risk factors related to stroke (age over 65 years, gender, family history, previous stroke, hypertension, cardiac disease, diabetes mellitus, and smoking), complications related to stroke (spasticity, dysarthria, contracture, neglect, urinary symptoms, dysphagia, pressure sores, deep vein thrombosis, heterotopic bone formation, etc.), ambulation, and functional and medication states of the patients were recorded. However, only data related to the objective of the study were used.

The cognitive state of each patient was evaluated using the mini-mental test (MMT). The validity and reliability of the MMT in Turkish were conducted in educated and uneducated patients $(21,22)$. In this study, patients with MMT scores of $>20$ were included. The standardized MMT form for the uneducated was used for illiterate patients.

For central neuropathic pain evaluation, the Leeds Assessment of Neuropathic Symptoms and Signs Pain Scale (LANSS), the validity and reliability of which has been examined in Turkish, was used in this study (23). If the total score in the LANSS scale was $<12$, calculated over 24 points, it was determined that neuropathic mechanisms did not play a predominant role in the patient's pain. If the total score was $\geq 12$, it was deter-

\section{Table 1. Demographic and clinical features of the cases}

\begin{tabular}{|c|c|c|}
\hline Age & Mean \pm SD & $60.27 \pm 11.59$ (min-max: 28-86, median: 61$)$ \\
\hline Gender & Female/Male & $47 / 53$ \\
\hline \multirow{6}{*}{\multicolumn{2}{|c|}{ Educational status }} & Illiterate: 24 \\
\hline & & Literate: 8 \\
\hline & & Primary School: 50 \\
\hline & & Secondary School: 8 \\
\hline & & Lycee: 9 \\
\hline & & High School: 1 \\
\hline \multirow{2}{*}{\multicolumn{2}{|c|}{ Stroke etiology }} & Ischemia: 77 \\
\hline & & Hemorrhage: 23 \\
\hline $\begin{array}{l}\text { Stroke } \\
\text { duration }\end{array}$ & Mean $\pm S D$ & 14.65 \pm 15.22 (min-max: 2-124 months, median: 9) \\
\hline \multirow{2}{*}{\multicolumn{2}{|c|}{ Side of the stroke }} & Right: 35 \\
\hline & & Left: 65 \\
\hline \multirow{2}{*}{\multicolumn{2}{|c|}{ Lesion localization }} & Extrathalamic: 87 \\
\hline & & Thalamic: 13 \\
\hline MMT & Mean $\pm S D$ & $25.30 \pm 3.25$ (min-max: $20-30$, median: 25$)$ \\
\hline
\end{tabular}




\begin{tabular}{|c|c|c|c|}
\hline & $\begin{array}{l}\text { Patients with central } \\
\text { pain }(n=12)\end{array}$ & $\begin{array}{l}\text { Patients without central } \\
\text { pain }(n=88)\end{array}$ & $p$ value \\
\hline Gender & $\mathrm{M} / \mathrm{F}: 5 / 7$ & M/F: 42/46 & 0.69 \\
\hline Age & $\begin{array}{l}64.00 \pm 12.12 \\
\text { (min-max: } 47-86, \text { median: } 65)\end{array}$ & $\begin{array}{l}59.76 \pm 11.49 \\
\text { (min-max: } 28-81, \text { median: } 61)\end{array}$ & 0.23 \\
\hline Stroke duration & $\begin{array}{l}\text { 13.42 } \pm 7.82 \\
\text { (min-max: } 7-34, \text { median:12) }\end{array}$ & $\begin{array}{l}\text { 14.82+15.99 } \\
\text { (min-max: } 2-124, \text { median: 9) }\end{array}$ & 0.76 \\
\hline MMT & $\begin{array}{l}24.17 \pm 2.36 \\
\text { (min-max:21-30, median: } 25)\end{array}$ & $\begin{array}{l}25.45 \pm 3.33 \\
\text { (min-max: } 20-30, \text { median: } 25)\end{array}$ & 0.20 \\
\hline $\mathrm{MBI}$ & $\begin{array}{l}64.58 \pm 21.47 \\
\text { (min-max: } 10-85, \text { median: } 70)\end{array}$ & $\begin{array}{l}66.08 \pm 20.55 \\
\text { (min-max: } 0-100, \text { median: } 70)\end{array}$ & 0.81 \\
\hline
\end{tabular}

MBI: modified Barthel Index, MMT: mini-mental test, M: male, F: female, min: minimum, max: maximum

Table 3. Mean Nottingham Health Profile Sub-Parameters and the comparison of Nottingham Health Profile sub-parameters of patients with and without central pain

\begin{tabular}{|c|c|c|c|c|}
\hline & $\begin{array}{l}\text { All patients } \\
(n=100)\end{array}$ & $\begin{array}{l}\text { Patients with central } \\
\text { pain }(n=12)\end{array}$ & $\begin{array}{l}\text { Patients without central } \\
\text { pain }(n=88)\end{array}$ & $p$ value \\
\hline Pain & $\begin{array}{c}32.44 \pm 30.68 \\
\text { (median: } 27.88 \\
\text { min-max: } 0.00-100.0)\end{array}$ & $\begin{array}{c}60.17 \pm 26.74 \\
\text { (median: } 59.40 \\
\text { min-max: } 9.99-100.0 \text { ) }\end{array}$ & $\begin{array}{c}28.66 \pm 29.33 \\
\text { (median: } 22.99 \\
\text { min-max: } 0.00-100.0)\end{array}$ & 0.001 \\
\hline Physical activity & $\begin{array}{c}68.29 \pm 19.36 \\
\text { (median: } 67.16 \\
\text { min-max: } 0.00-100.0 \text { ) }\end{array}$ & $\begin{array}{c}67.46 \pm 15.62 \\
\text { (median: } 67.16 \\
\text { min-max: } 32.70-88.46)\end{array}$ & $\begin{array}{c}68.41 \pm 19.89 \\
(\text { median: } 67.16 \\
\text { min-max: } 0.00-100.0)\end{array}$ & 0.87 \\
\hline Fatigue & $\begin{array}{c}63.79 \pm 36.26 \\
\text { (median: } 76.00 \\
\text { min-max: } 0.00-100.0 \text { ) }\end{array}$ & $\begin{array}{c}70.93 \pm 27.20 \\
\text { (median: } 76.00 \\
\text { min-max: } 36.80-100.0 \text { ) }\end{array}$ & $\begin{array}{c}62.82 \pm 37.35 \\
\text { (median: } 76.00 \\
\text { min-max: } 0.00-100.0)\end{array}$ & 0.47 \\
\hline Sleep & $\begin{array}{c}31.62 \pm 32.32 \\
\text { (median: } 27.26 \\
\text { min-max: } 0.00-100.0 \text { ) }\end{array}$ & $\begin{array}{c}27.73 \pm 37.51 \\
\text { (median: } 11.18 \\
\text { min-max: } 0.00-100.0)\end{array}$ & $\begin{array}{c}32.15 \pm 31.75 \\
\text { (median: } 27.26 \\
\text { min-max: } 0.00-100.0)\end{array}$ & 0.65 \\
\hline Social isolation & $\begin{array}{c}50.06 \pm 24.90 \\
\text { (median: } 44.54 \\
\text { min-max: } 0.00-100.0 \text { ) }\end{array}$ & $\begin{array}{c}54.80 \pm 25.08 \\
\text { (median: } 44.54 \\
\text { min-max: } 22.53-100.0 \text { ) }\end{array}$ & $\begin{array}{c}49.42 \pm 24.95 \\
\text { (median: } 44.54 \\
\text { min-max: } 0.00-100.0)\end{array}$ & 0.48 \\
\hline Emotional reactions & $\begin{array}{c}34.95 \pm 20.50 \\
\text { (median: } 34.95 \\
\text { min-max: } 0.00-86.01 \text { ) }\end{array}$ & $\begin{array}{c}35.62 \pm 18.48 \\
\text { (median: } 39.09 \\
\text { min-max: } 9.76-78.68 \text { ) }\end{array}$ & $\begin{array}{c}34.86 \pm 20.86 \\
\text { (median: } 32.64 \\
\text { min-max: } 0.00-86.01 \text { ) }\end{array}$ & 0.90 \\
\hline
\end{tabular}

Min: minimum, max: maximum

mined that neuropathic mechanisms did play a predominant role in the patient's pain.

The functional status of each case was evaluated using the modified Barthel Index (MBI) because its adaptation in Turkish has already been conducted (24).

The Nottingham Health Profile (NHP) was used to evaluate the quality of life. The NPH comprised six sub-parts, which evaluates patient perception of emotional, social, and physical health problems as follows: 1) Energy level (three sub-parameters); 2) Pain (eight sub-parameters); 3) Physical activity (eight sub-parameters); 4) Sleep (five sub-parameters); 5) Emotional reactions (nine sub-parameters); and 6) Social isolation (five sub-parameters). The questionnaire is composed of 38 questions, which are answered as "yes" or "no." It asks about the patient's current complaints. Positive answers given in specific areas determined the scoring of the scales, and the sum of these scores evaluates the intensity. The total score of every sub-category is 100 . The sum of the sub-categories can be given as a profile (25). The NPH is a test that has been adapted for the Turkish population (26). Six sub-parameters of the NPH were evaluated in all the cases included in this study.

\section{Statistical Analysis}

Statistical analysis was performed using the Statistical Package for the Social Sciences 15.0 (SPSS, INC., Chicago, IL, USA) for Windows. Descriptive statistics were used for determining the mean values and frequencies. The Mann-Whitney $U$ test and Chi-square test were employed for two-group comparisons. Spearman's correlation test was used to detect correlations. A value of $\mathrm{p}<0.05$ was accepted to be statistically significant. 


\section{Results}

In total, 100 stroke patients (47 women, 53 men) were included in the study, with an age range from 28 to 86 years and a mean age of $60.27 \pm 11.59$ years. The demographic and clinical features of the patients are summarized in Table 1.

When risk factors were considered, 38 out of the 100 patients were over 65 years, 82 had hypertension, 37 had cardiac disease, 19 had previous stroke, 35 had diabetes mellitus, 27 had a significant family history, 39 had a history of smoking, and 53 were male.

The scores of patients whose activities of daily living were evaluated using the $\mathrm{MBI}$ were between 0 and 100 . The mean $\mathrm{MBI}$ score was $25.90 \pm 20.56$. According to the $\mathrm{MBI}$ score, 4 cases were completely dependent, 31 were highly dependent, 61 were moderately dependent, 1 was mildly dependent, and 3 were independent.

Patients with and without central pain were compared with regard to demographics and clinical features. Table 2 shows that there was no significant difference with respect to these compared features.

With regard to central post-stroke pain, central pain was detected in 12 out of the 100 patients (12\%). The mean LANSS score of patients complaining of central pain was 17.75 (14-24).

In the NPH questionnaire, the scores for pain, physical activity, fatigue, and social isolation from the six sub-categories varied between 0 and 100, and the emotional reaction score varied between 0 and 86.01. When the sub-parameters of NPH were compared between patients with and without central pain, only the pain parameter was significantly different between the two groups (Table 3).

\section{Discussion}

Central post-stroke pain develops within 1-2 months after stroke in $40 \%-80 \%$ of patients. Within this period, either central pain cannot be detected or detection is delayed because the patients are not in rehabilitation clinics, do not have an adequate level of cognition to express themselves, or are aphasic. In this study, the incidence of central post-stroke pain was $12 \%$, and central pain, in general, did not affect the patient's quality of life, apart from one pain sub-category as evaluated by NPH.

In our patient group, the duration between stroke onset and questioning varied from 2 to 124 months. It is known that central post-stroke pain mostly occurs in the first month after stroke. However, because the stroke patients were admitted into rehabilitation clinics after the first month, i.e., when the general condition of the patient had stabilized, pain questioning could only be performed later than the first month post-stroke. In studies conducted in different countries worldwide, the incidence of central post-stroke pain is reported to be between $8.6 \%$ and $35 \%$ (6-10). Therefore, in our study, the incidence of central post-stroke pain was similar to the incidence rates reported in the literature (12\%).

Many cerebral regions process pain, and there is no single localized pain center in the brain (27). In studies conducted on central post-stroke pain, because central pain was first defined in thalamic lesions, cerebral localization is classified as thalamic and extra-thalamic. In support of this, in our study, the cerebral lesion was thalamic in 4 out of the 12 patients with central post-stroke pain and was extra-thalamic in 8 patients $(2,6,28)$. Lesions with a complete or partial localization may affect the development of central pain. In an investigation on patients with intracerebral hemorrhage, a higher rate of central post-stroke pain was observed in patients with partial spinothalamic tract lesions than in patients with complete lesions (29).

The quality of life is affected by social, economic, functional, and spiritual factors (30-33). Within the first year after stroke, economic status and the current functional capacity of an individual have been detected as indicators of the quality of life (34). It has been reported that the quality of life increases with higher functional independence $(35,36)$. In a study investigating the relationship of impairment, disability, and the quality of life, a positive correlation among the Barthel Index, Frenchay Activities Index, and Short Form (SF)-36 physical activity subscale was detected (37).

Choi-Kwon et al. (14) detected an impaired quality of life in the first 3 months after stroke. In addition, they found that within 3 years after stroke, dependence in activities of daily living, motor dysfunction, depression, central post-stroke pain, low economic status, and unemployment factors were associated with poor quality of life. Moreover, they suggested that dependence in activities of daily living (19\%), presence of central post-stroke pain (12\%), and low economic status (10\%) were the factors that most greatly contributed to the quality of life as a whole and that central post-stroke pain was the most important factor in the physical and psychological sub-groups of the quality of life sub-group analysis.

In studies conducted in Turkey, female gender, susceptibility to depression, presence of multiple comorbidities, and poor functional state have been emphasized as indicators for poor quality of life $(38,39)$. Rachpukdee et al. (40) suggested that increased dependency, cognitive disorders, right hemisphere lesions, being single or widowed, being over the age of 60 years, being unemployed, having difficulties in self-care, and difficulties in covering medical costs all negatively affected the quality of life.

In another study, although the post-stroke and long-term functional states of the patients were good, it was suggested that lower scores were obtained in all sub-parameters of the SF36 in stroke patients than in controls (15). It was found that stroke patients who were over 65 years of age had greater difficulty in achieving their goals in activities of daily living and returning to professional lives (16). It has been emphasized that the quality of life is lower at more advanced ages and that these patients have a higher risk of mortality (17).

There are many studies indicating that stroke pain, in particular central pain, affects the quality of life. In these studies, it has been reported that pain is associated with depression, sleep disorders, fatigue, poor physical condition, mood changes, and stress $(18,19,41-43)$.

Bergés et al. (20) found that although quality of life was effected in both gender by central poststroke pain and, male 
patients had been effected more than female patients. In our study when we evaluated central post-stroke pain, we detected a significant difference in the pain sub-parameter of the NPH between patients with and without central post-stroke pain. In other words, the quality of life was negatively affected because of central post-stroke pain. These findings are consistent with previous studies regarding the quality of life.

Our study has some limitations. The time at which the central pain began, the features of the pain, medical treatment, and depression were not assessed. Current somatosensory disorders and pain, apart from central pain, were evaluated but not recorded. Moreover, the limited number of patients, the fact that the study was conducted in one center, and the cross-sectional nature of the study may represent additional limitations.

\section{Conclusion}

The aim of this study was to detect the incidence of central post-stroke pain and determine how it affected the quality of life in our patients. Further comprehensive studies using the content and technical features of this present study are needed for the evaluation and treatment of central post-stroke pain and to improve the quality of life of patients.

Ethics Committee Approval: Ethics committee approval was received for this study from the ethics committee of Istanbul Physical Medicine Rehabilitation Training and Research Hospital.

Informed Consent: Written informed consent was obtained from patients who participated in this study.

Peer-review: Externally peer-reviewed.

Author Contributions: Concept - Z.K.; Design - Z.K., B.E.; Supervision - B.E.; Resource - Z.K., G.I.E.; Materials - Z.K.; Data Collection and/ or Processing - Z.K.; Analysis and/or Interpretation - B.E.,B.G.; Literature Review - Z.K., G.I.E.; Writer - Z.K.; Critical Review - B.E., B.G.

Conflict of Interest: No conflict of interest was declared by the authors.

Financial Disclosure: The authors declared that this study has received no financial support.

\section{References}

1. Leijon G, Boivie J, Johansson I. Central post-stroke pain-neurological symptoms and pain characteristics. Pain 1989;36:13-25. [CrossRef]

2. Bowsher D. The management of central post-stroke pain. Postgrad Med J 1995;71: 598-4. [CrossRef]

3. Nicholson BD. Evaluation and treatment of central pain syndromes. Neurology 2004;62:S30-6. [CrossRef]

4. Bowsher D. Central post-stroke (thalamic syndrome) and other central pains. Am J Hosp Palliat Care 1999;16:593-7. [CrossRef]

5. Kumar B, Kalita J, Kumar G, Misra UK. Central poststroke pain: a review of pathopysiology and treatment. Anesth Anal 2009;108:164557. [CrossRef]

6. Andersen $G$, Vestergaard K, Ingema-Nielsen $M$, Jensen TS. Incidence of central post-stroke pain. Pain 1995;61:187-93. [CrossRef]
7. Widar M, Samuelsson L, Karlsson-Tivenius S, Ahlström G. Longterm pain conditions after a stroke. J Rehabil Med 2002;34:165-70. [CrossRef]

8. Hansen AP, Marcussen NS, Klit H, Andersen G, Finnerup NB, Jensen TS. Pain following stroke: a prospective study. Eur J Pain 2012;16:1128-36. [CrossRef]

9. Kong $\mathrm{KH}$, Woon VC, Yang SY. Prevalence of chronic pain and its impact on health-related quality of life in stroke survivors. Arch Phys Med Rehabil 2004;85:35-40. [CrossRef]

10. Klit H, Finnerup NB, Andersen $G$, Jensen TS. Central poststroke pain: a population- based study. Pain 2011;152:818-24. [CrossRef]

11. Takahashi Y, Hashimoto K, Tsuji S. Successful use of zonisomide for central poststroke pain. J Pain 2004;5:192-4. [CrossRef]

12. Flaster $M$, Meresh E, Rao M, Biller J. Central poststroke pain: current diagnosis and treatment Top Stroke Rehabil 2013;20:116-23. [CrossRef]

13. Boivie J, Leijon G, Johansson I. Central post-stroke pain: a study of the mechanisms through analyses of the sensory abnormalities. Pain 1989;37:173-85. [CrossRef]

14. Choi-Kwon S, Choi JM, Kwon SU, Kang DW, Kim JS. Factors that Affect the Quality of Life at 3 years poststroke. I Clin Neurol 2006;2:34-41. [CrossRef]

15. Naess $H$, Waje-Andreassen $U$, Thomassen L, Nyland H, Myhr KM. Health-related quality of life among young adults with ischemic stroke on long-term follow-up. Stroke 2006;3:1232-6. [CrossRef]

16. Kotila M. Four year prognosis of patients under the age of 65 surviving their first ischemic brain infarction. Ann Clin Res 1986;18:76-9.

17. Sharma JS, Fletcher S, Vassalo M. Strokes in the elderly. Higher acute and 3rd month mortality. An explanation. Cerebrovasc Dis 1999;9:2-9. [CrossRef]

18. Kwok T, Lo RS, Wong E, Wai-Kwong T, Mok V, Kai-Sing W. Quality of life of stroke survivors a 1 year follow up study. Arch Phys Med Rehabil 2006;87:1177-82. [CrossRef]

19. Kong KH, Woon VC, Yang SY. Prevalence of chronic pain and its impact on health-related quality of life in stroke survivors. Arch Phys Med Rehabil 2004;85:35-40. [CrossRef]

20. Bergés IM, Ottenbacher KJ, Kuo YF, Smith PM, Smith D, Ostir GV. Satisfaction with quality of life post stroke: effect of sex differences in pain response. Arch Phys Med Rehabil 2007;88:413-7. [CrossRef]

21. Güngen C, Ertan T, Eker E, Yaşar R, Engin F. Reliability and validity of the standardized Mini Mental State Examination in the diagnosis of mild dementia in Turkish population. Turk Psikiyatri Derg 2002;13:273-81.

22. Ertan T, Eker, Güngen C. The Standardized Mini Mental State Examination for illiterate Turkish elderly population, 2nd International Symposium on Neurophysiological and Neuropsychological Assessment of Mental and Behavioral Disorders, 28-30 Ağustos 1999, Bursa.

23. Yücel A, Senocak M, Kocasoy Orhan E, Cimen A, Ertas M. Results of the Leeds assessment of neuropathic symptoms and signs pain scale in Turkey: a validation study. J Pain 2004;5:427-32. [CrossRef]

24. Küçükdeveci AA, Yavuzer G, Tennant A, Süldür N, Sonel B, et al. Adaptation of the modified Barthel index for use in physical medicine and rehabilitation in Turkey. Scand J Rehabil Med 2000;32: 87-92. [CrossRef]

25. Gokkaya NK, Aras MD, Cakci A. Health-related quality of life of Turkish stroke survivors. Int J Rehabil Res 2005;28:229-35. [CrossRef]

26. Küçükdeveci AA, McKenna SP, Kutlay S, Gürsel Y, Whalley D, Arasil T. The development and psychometric assessment of the Turkish version of the Nottingham Health Profile. Int J Rehabil Res 2000;23:31-8. [CrossRef] 
27. Aydın ON. Ağrı ve Ağrı Mekanizmalarına Güncel Bakış. ADÜ Tıp Fakültesi Dergisi 2002;3:37-8.

28. Misra UK, Kalita J, Kumar B. A study of clinical, magnetic resonance imaging, and somatosensory-evoked potential in central poststroke pain. J Pain 2008;9:1116-22. [CrossRef]

29. Hong JH, Choi BY, Chang CH, Kim SH, Jung Y], Lee DG, et al. The prevalence of central poststroke pain according to the integrity of the spino-thalamo-cortical pathway. Eur Neurol 2012;67:12-7. [CrossRef]

30. Carod-Artal FJ, Egido JA. Quality of life after stroke: the importance of a good recovery, Cerebrovasc Dis 2009;27:204-14. [CrossRef]

31. Carod-Artal FJ. Determining quality of life in stroke survivors, Expert Rev Pharmacoecon Outcomes Res 2012;12:199-211. [CrossRef]

32. Carod-Artal J, Egido JA, González JL, Varela de Seijas E. Quality of life among stroke survivors evaluated 1 year after stroke: experience of a stroke unit, Stroke 2000;31:2995-3000. [CrossRef]

33. Haghgoo HA, Pazuki ES, Hosseini AS, Rassafiani M. Depression, activities of daily living and quality of life in patients with stroke. Neurol Sci 2013;328:87-91. [CrossRef]

34. Larson J, Franzen-Dahlin A, Billing E, Arbin M, Murray V, Wredling R. Predictors of quality of life among spouses of stroke patients during the first year after the stroke event. Scand J Caring Sci 2005;19:439-45.

35. Indredavik B, Bakke F, Slordahl SA, Rokseth R, Haheim LL. Stroke unit treatment improves long term quality of life a randomized controlled trial. Stroke 1998;29:295-9. [CrossRef]
36. Şenocak Ö, El Ö, Söylev GÖ, Avcılar S, Peker Ö. Inme sonrasında yaşam kalitesini etkileyen faktörler. J Neurol Sci (Turk) 2008;25:169-5. [CrossRef]

37. Patel MD, Tilling K, Lawrence E, Rudd AG, Wolfe CD, McKevitt C. Relationship between long term stroke disability, handicap and health-related quality of life. Age Ageing 2006;35:273-9. [CrossRef]

38. Gokkaya NK, Aras MD, Cakci A. Health-related quality of life of Turkish stroke survivors, Int J Rehabil Res 2005;28:229-35. [CrossRef]

39. Ones K, Yilmaz E, Cetinkaya B, Caglar N. Quality of life for patients poststroke and the factors affecting it. J Stroke Cerebrovasc Dis 2005;14:261-6. [CrossRef]

40. Rachpukdee S, Howteerakul N, Suwannapong N, Tang-Aroonsin S. Quality of life of stroke survivors: a 3-month follow-up study. J Stroke Cerebrovasc Dis 2013;22:e70-8. [CrossRef]

41. Appelros P. Prevalence and predictors of pain and fatigue after stroke: a population-based study. Int J Rehabil Res 2006;29:329-33. [CrossRef]

42. Widar M, Ek AC, Ahlström G. Coping with long-term pain after a stroke. J Pain Symptom Manage 2004;27:215-25. [CrossRef]

43. Tarsuslu T, Yümin ET, Oztürk A, Yümin M. The relation between health-related quality of life and pain, depression, anxiety, and functional independence in persons with chronic physical disability. Agri 2010;22:30-6. 